JPPKMI 1 (1) (2020)
JURNAL PENELITIAN DAN PENGEMBANGAN
KESEHATAN MASYARAKAT INDONESIA
Jttps://journal.unnes.ac.id/sju/index.php/jppkmi

\title{
Perilaku Pencegahan Covid-19 Ditinjau dari Karakteristik Individu dan Sikap Masyarakat
}

\author{
Ayu Riana Sari ${ }^{1} \bowtie$, Fauzie Rahman ${ }^{1}$, Anggun Wulandari $^{1}$, Nita Pujianti $^{1}$, Nur Laily ${ }^{1}$, Vina \\ Yulia Anhar ${ }^{1}$, Lia Anggraini ${ }^{1}$, Muhammad Azmiyannoor ${ }^{1}$, Agus Muhammad Ridwan², \\ Farid Ilham Ilham Muddin ${ }^{2}$
}

${ }^{1}$ Program Studi Kesehatan Masyarakat, Fakultas Kedokteran, Universitas Lambung Mangkurat Banjarbaru, Indonesia

${ }^{2}$ Program Studi Magister Ilmu Kesehatan Masyarakat, Universitas Lambung Mangkurat Banjarbaru, Indonesia

\section{Info Artikel \\ Sejarah Artikel: \\ Diterima Mei 2020 \\ Disetujui Juni 2020 \\ Dipublikasikan Juli 2020}

\section{Keywords:}

prevention, covid-19,

individual characteristics,

attitude, education

\section{URL:}

https://iournal.unnes.ac.j d/sju/index.php/ippkmi /article/view/41428/173 $\underline{39}$

\begin{abstract}
Abstrak
Pendahuluan: Covid-19 sudah dikategorikan sebagai pandemi global. Covid-19 merupakan jenis virus yang baru sehingga banyak pihak yang tidak tahu dan tidak mengerti cara penanggulangan virus tersebut. Tujuan penelitian ini adalah untuk mengetahui hubungan antara karakteristik individu dan sikap terkait pencegahan Covid-19 dengan perilaku pencegahan Covid-19. Metode: Penelitian ini merupakan jenis penelitian cross-sectional. Sampel dalam penelitian ini berjumlah 1.170 orang dan dipilih dengan menggunakan purposive sampling. Pengumpulan data dengan menggunakan kuesioner yang dibantu dengan program google form. Hasil: Hasil penelitian menunjukan bahwa mayoritas responden dalam penelitian ini adalah remaja (90,90\%), mempunyai status bekerja $(56,00 \%)$, berjenis kelamin perempuan $(69,30 \%)$, memiliki sikap positif terhadap pencegahan covid-19 $(99,15 \%)$ dan mempunyai perilaku yang baik terhadap pencegahan covid-19 $(90,20 \%)$. Hasil uji chi-square menunjukan nilai $\mathrm{p}$ antara jenis kelamin, umur, status pekerjaan, dan sikap terkait pencegahan Covid-19 dengan perilaku pencegahan Covid-19 adalah 0,000, 0,306, 0,605 dan 0,066. Penutup: Kesimpulannya adalah ada hubungan yang signifikan antara jenis kelamin dengan perilaku pencegahan Covid-19. Namun, tidak ada hubungan yang signifikan antara umur, status pekerjaan, dan sikap terkait pencegahan Covid-19 dengan perilaku pencegahan Covid-19.
\end{abstract}

\begin{abstract}
Introduction: Covid-19 has been categorized as a global pandemic. Covid-19 is a new type of virus so that many parties do not know and do not understand how to deal with the virus. The purpose of this study was to see the relationship between individual characteristics and attitudes related to Covid-19 prevention and Covid19 prevention behavior. Methods: Cross sectional design with a sample taken 1170 people selected using purposive sampling. Data collection using a questionnaire assisted by the google form program. Results: The results showed that the group of respondents in this study were adolescents (90.90\%), had a working status (56.00\%), were female (69.30\%), had a positive attitude towards the prevention of Covid-19 (99,15 )\%) and good behavior for the prevention of covid-19 (90.20\%). The results of the chi-square test showed the values between sex, age, work status, and prevention of Covid-19 prevention and Covid-19 prevention were 0.000, 0.306, 0.605 and 0.066. Closing: The conclusion is that there is a significant relationship between gender and Covid-19 prevention behavior. However, there was no significant correlation between age, employment status, and attitudes related to Covid-19 prevention and Covid-19 prevention behavior.
\end{abstract}

\ Alamat korespondensi:

J1. Veteran Sungai Bilu No.128, Melayu, Kec. Banjarmasin

Tengah, Kota Banjarmasin, Kalimantan Selatan 70122

E-mail: avumumtaz89@gmail.com 


\section{PENDAHULUAN}

Covid-19 saat ini menjadi permasalahan dunia yang serius dengan jumlah kasusnya yang selalu mengalami peningkatan setiap harinya, menyerang setiap orang tanpa memandang usia maupun jenis kelamin dan sudah dikategorikan sebagai pandemi global (Setiawan, 2020). Covid-19 merupakan jenis virus yang baru sehingga banyak pihak yang tidak tahu dan tidak mengerti cara penanggulangan virus tersebut. Gejala yang ditimbulkan oleh Covid19 hampir menyerupai dengan flu pada umumnya. Saat ini, penyebaran SARS-CoV-2 dari manusia ke manusia menjadi sumber transmisi utama sehingga penyebaran menjadi lebih agresif (Telaumbanua, 2020; WHO, 2020).

Pandemi global Covid-19 pertama kali diumumkan pada 11 Maret 2020 menandakan bahwa virus ini sudah menjangkiti populasi besar di berbagai negara. Pada tanggal 25 Maret 2020 sudah menjangkiti 175 negara dengan angka penularan sebanyak 425.493 kasus (JHU, 2020). China masih menempati posisi tertinggi, yaitu 81.637 kasus, tetapi kasus kesembuhan di China juga tinggi, yaitu 73.770 kasus sehingga kasus Covid-19 di China sudah terkendali. Pada 2 Maret 2020, dua kasus pertama dikonfirmasi Indonesia.

Covid-19 merupakan penyakit yang baru ditemukan oleh karena itu pengetahuan terkait pencegahannya masih terbatas. Tanda dan gejala umum infeksi Covid-19 antara lain gejala gangguan pernapasan akut seperti demam, batuk dan sesak napas. Masa inkubasi rata-rata 5-6 hari dengan masa inkubasi terpanjang 14 hari. Pada kasus Covid-19 yang berat dapat menyebabkan pneumonia, sindrom pernapasan akut, gagal ginjal, dan bahkan kematian. Tandatanda dan gejala klinis yang dilaporkan pada sebagian besar kasus adalah demam, dengan beberapa kasus mengalami kesulitan bernapas, dan hasil rontgen menunjukkan infiltrat pneumonia luas di kedua paru (Dirjen P2P, 2020).

Kunci pencegahan meliputi pemutusan rantai penularan dengan isolasi, deteksi dini, dan melakukan proteksi dasar. Rekomendasi
WHO dalam menghadapi wabah Covid-19 adalah melakukan proteksi dasar, yang terdiri dari cuci tangan secara rutin dengan alkohol atau sabun dan air, menjaga jarak dengan seseorang yang memiliki gejala batuk atau bersin, melakukan etika batuk atau bersin, dan berobat ketika memiliki keluhan yang sesuai kategori suspek. Untuk itu sementara waktu hindari kerumuman dan tetap tinggal dirumah serta jagalah keluarga agar tetap sehat dan terhindar dari penyakit karena keluarga sangat penting bagi kita (WHO, 2020; Adityo, 2020).

Masyarakat merupakan pihak yang berperan signifikan dalam memutus rantai penularan Covid-19. Sikap masyarakat yang patuh terhadap protokol kesehatan akan dapat menurunkan kasus Covid-19. Penyakit komorbid hipertensi dan diabetes melitus, jenis kelamin laki-laki, dan perokok aktif merupakan faktor risiko dari penyakit Covid-19 (Fang, 2020; Cai, 2020). Tujuan penelitian ini adalah untuk mengetahui hubungan antara karakteristik individu dan sikap terkait pencegahan Covid-19 dengan perilaku pencegahan Covid-19.

\section{METODE}

Penelitian ini merupakan jenis penelitian cross-sectional. Metode yang digunakan adalah dengan pendekatan kuantitatif. Pendekatan kuantitatif digunakan untuk mengetahui hubungan antara variabel bebas dengan variabel terikat. Adapun variabel bebas yang digunakan pada penelitian ini adalah sikap dan dukungan keluarga, sedangkan variabel terikatnya berupa perilaku pencegahan covid-19. Sampel dalam penelitian ini berjumlah 1.170 orang dan dipilih dengan menggunakan purposive sampling. Pengumpulan data dengan menggunakan kuesioner yang dibantu dengan program google form. Analisa data dilakukan secara univariat dan bivariat (uji chi-square). Penelitian ini berlangsung pada bulan April 2020.

\section{HASIL DAN PEMBAHASAN}

Mayoritas responden dalam penelitian ini 
Tabel 1. Distribusi dan Frekuensi Karakteristik Responden, Sikap, dan Perilaku Pencegahan Covid19 .

\begin{tabular}{|c|c|c|c|}
\hline No & Variabel & Frekuensi & Persentase (\%) \\
\hline 1. & Karakteristik responden & & \\
\hline \multirow[t]{4}{*}{ a. } & Umur responden & & \\
\hline & Remaja (12-25 tahun) & 1.063 & 90,9 \\
\hline & Dewasa (26-45 tahun) & 67 & 5,7 \\
\hline & Lansia (46-65 tahun) & 40 & 3,4 \\
\hline \multirow[t]{3}{*}{ b. } & Pekerjaan responden & & \\
\hline & Bekerja & 655 & 56 \\
\hline & Tidak bekerja & 515 & 44 \\
\hline \multirow[t]{3}{*}{ c. } & Jenis Kelamin responden & & \\
\hline & Laki-laki & 359 & 30,7 \\
\hline & Perempuan & 811 & 69,3 \\
\hline \multirow[t]{3}{*}{2} & Sikap & & \\
\hline & Positif & 1160 & 99,15 \\
\hline & Negatif & 10 & 0,85 \\
\hline \multirow[t]{3}{*}{3} & Perilaku pencegahan covid-19 & & \\
\hline & Baik & 1.055 & 90,2 \\
\hline & Tidak baik & 115 & 9,8 \\
\hline \multicolumn{2}{|c|}{ Jumlah } & 1170 & 100 \\
\hline
\end{tabular}

Tabel 2. Hubungan Karakteristik Individu (Jenis Kelamin, Umur, dan Status Pekerjaan) dan Sikap dengan Perilaku Pencegahan Covid-19

\begin{tabular}{|c|c|c|c|c|c|c|c|c|}
\hline \multirow{3}{*}{ No. } & \multirow{3}{*}{ Variabel } & \multicolumn{4}{|c|}{ Perilaku Pencegahan COVID-19 } & \multirow{2}{*}{\multicolumn{2}{|c|}{ Total }} & \multirow{3}{*}{$p$-valu } \\
\hline & & \multicolumn{2}{|c|}{ Baik } & \multicolumn{2}{|c|}{ Tidak baik } & & & \\
\hline & & $\mathrm{n}$ & $\%$ & $\mathrm{~N}$ & $\%$ & $\mathrm{n}$ & $\%$ & \\
\hline 1 & Karakteristik individu & & & & & & & \\
\hline \multirow[t]{3}{*}{$\mathrm{a}$} & Jenis kelamin & & & & & & & \multirow{5}{*}{0,000} \\
\hline & Laki-laki & 276 & 76,88 & 83 & 23,12 & 359 & 100 & \\
\hline & Perempuan & 721 & 88,90 & 90 & 11,10 & 811 & 100 & \\
\hline \multirow[t]{4}{*}{$\mathrm{b}$} & Umur & & & & & & & \\
\hline & Remaja & 898 & 84,48 & 165 & 15,52 & 1063 & 100 & \\
\hline & Dewasa & 62 & 92,54 & 5 & 7,46 & 67 & 100 & \multirow{2}{*}{0,306} \\
\hline & Lansia & 37 & 92,50 & 3 & 7,50 & 40 & 100 & \\
\hline \multirow[t]{3}{*}{ c } & Status Pekerjaan & & & & & & & \multirow{4}{*}{0,605} \\
\hline & Bekerja & 958 & 85,31 & 165 & 14,69 & 1123 & 100 & \\
\hline & Tidak bekerja & 39 & 82,98 & 8 & 17,02 & 47 & 100 & \\
\hline \multirow[t]{3}{*}{2} & Sikap & & & & & & & \\
\hline & Positif & 1048 & 90,30 & 112 & 9,70 & 1160 & 100 & \multirow{2}{*}{0,066} \\
\hline & Negatif & 7 & 70,00 & 3 & 30,00 & 10 & 100 & \\
\hline
\end{tabular}

adalah remaja $(90,90 \%)$, mempunyai status bekerja $(56,00 \%)$, berjenis kelamin perempuan $(69,30 \%)$, memiliki sikap positif terhadap pencegahan covid-19 $(99,15 \%)$ dan mempunyai perilaku yang baik terhadap pencegahan covid$19(90,20 \%)$ (Tabel 1).

Responden yang memiliki jenis kelamin perempuan dan memiliki perilaku pencegahan covid-19 yang baik sebanyak $88,90 \%$, sedangkan yang laki-laki dan memiliki perilaku pencegahan covid-19 yang baik hanya sebesar $76,88 \%$. Ada hubungan antara jenis kelamin dengan perilaku pencegahan covid-19 (p-value $=0,000)$. Responden yang termasuk dalam kategori umur remaja dan memiliki perilaku pencegahan covid-19 yang baik sebanyak $84,48 \%$, responden yang termasuk dalam kategori umur dewasa dan memiliki perilaku pencegahan covid-19 yang baik sebanyak $92,54 \%$, dan responden yang termasuk dalam kategori umur lansia dan memiliki perilaku pencegahan covid-19 yang baik sebanyak $92,50 \%$. Tidak ada hubungan 
antara umur dengan perilaku pencegahan covid19 (p-value $=0,306)$.

Responden yang bekerja dan memiliki perilaku pencegahan covid-19 yang baik sebanyak $85,31 \%$, sedangkan yang tidak bekerja dan memiliki perilaku pencegahan covid-19 yang baik hanya sebesar $82,98 \%$. Tidak ada hubungan antara status pekerjaan dengan perilaku pencegahan covid-19 ( $p$-value $=0,605)$. Responden yang memiliki sikap positif dan memiliki perilaku pencegahan covid-19 yang baik sebanyak 90,30\%, sedangkan yang memiliki sikap negatif dan memiliki perilaku pencegahan covid-19 yang baik hanya sebesar $70,00 \%$. Tidak ada hubungan antara status pekerjaan dengan perilaku pencegahan covid-19 (p-value $=0,066)$.

Penelitian ini menunjukan bahwa ada hubungan antara jenis kelamin dengan perilaku pencegahan covid-19. Teori Green mengatakan bahwa jenis kelamin termasuk faktor predisposisi atau faktor pemungkin yang memberi kontribusi terhadap perilaku kesehatan seseorang. Jenis kelamin perempuan cenderung lebih peduli terhadap kondisi lingkungan dan kesehatannya. Perempuan mempunyai kecenderungan berperilaku baik dibandingkan dengan laki-laki. Fenomena tersebut menghasilkan perempuan yang lebih peduli terhadap kondisi lingkungan dan kesehatannya. Kasus kematian COVID-19 di Indonesia didominasi oleh jenis kelamin laki-laki. Hal ini diduga terkait laki-laki yang masih kerap keluar rumah dibandingkan dengan isolasi diri di rumah (FArihatun, 2016; Susilo, 2020). Berdasarkan hasil penelitian yang dilakukan oleh Wulandari A, dkk (2020), diketahui bahwa masyarakat dengan jenis kelamin perempuan cenderung memiliki pengetahuan yang lebih baik tentang pencegahan Covid-19 jika dibandingkan dengan laki-laki. Hal ini disebabkan karena masyarakat dengan jenis kelamin perempuan memiliki lebih banyak waktu untuk membaca atau berdiskusi dengan lingkungannya terkait pencegahan Covid-19 (Wulandari, 2020).

Selain itu, penelitian ini menunjukan bahwa tidak ada hubungan antar umur terhadap perilaku pencegahan covid-19 dengan perilaku pencegahan covid-19. Rentang umur 36-45 merupakan usia matang dengan pertimbangan seseorang pada umur tersebut akan memiliki pola tangkap dan daya pikir yang baik sehingga pengetahuan yang dimilikinya juga akan semakin membaik. Akan tetapi, ada 6 faktor fisik yang dapat menghambat proses belajar pada orang dewasa diantaranya gangguan penglihatan dan pendengaran sehingga membuat penurunan pada suatu waktu dalam kekuatan berfikir dan bekerja (Maulana, 2007). Faktor lain yang juga menghambat adalah kondisi fisiologis dan psikologi seseorang seperti kondisi seseorang ketika sakit atau ada keterbatasan dalam indra. Pada penelitian ini, tidak adanya hubungan antara umur dengan perilaku pencegahan Covid-19 dapat dikarenakan adanya proporsi yang hampir sama antara kelompok umur remaja, dewasa dan lansia dengan perilaku pencegahan covid-19 yang baik.

Penelitian ini juga menunjukan bahwa tidak adanya hubungan antara status pekerjaan dengan perilaku pencegahan Covid-19 disebabkan karena antara responden yang bekerja dan tidak bekerja dengan perilaku pencegahan covid-19 yang baik jumlahnya hampir sama. Hal ini juga sejalan dengan penelitian Saqlain dkk (2020) bahwa tidak ada hubungan antara pekerjaan dengan tindakan mengenai COVID 19 pada tenaga kesehatan. Status pekerjaan tidak berhubungan dengan perilaku pencegahan COVID 19 kemungkinan dikarenakan responden melakukan pencegahan COVID 19 walaupun mereka tidak bekerja. Kemungkinan juga hal ini dapat dikaitkan dengan umur responden yang kebanyakan adalah pada kategori remaja.

Sikap merupakan faktor predisposisi (predisposing factors) dalam seseorang melakukan perilaku tertentu. Dalam melakukan pencegahan penyakit, sikap merupakan salah satu faktor yang mempengaruhi seseorang dalam mencegah terjangkitnya suatu penyakit karena dalam upaya pencegahan penyakit pasti berhubungan dengan sikap masyarakat. 
Sehingga sikap merupakan salah satu faktor pendukung dalam perilaku pencegahan penyakit. Sikap juga dipengaruhi oleh pengetahuan, pengetahuan yang baik tentang pencegahan covid-19 juga menjadi dasar dalam sikap yang baik dalam perilaku pencegahan covid-19, yang berarti pengetahuan berpikir memegang peranan penting dalam pembentukan sikap (Sari, 2017; Edison, 2020).

Sikap adalah cerminan pertama yang terlihat dari seorang manusia ketika ia bertingkah laku. Sikap merupakan suatu adopsi dari gejala di dalam diri masyarakat yang memiliki dimensi afektif yang merupakan kecenderungan untuk dapat mereaksi atau melakukan respon (response tedency) melalui cara yang relatif tetap terhadap objek barang, dan manusia, baik secara baik maupun tidak baik. Sikap akan berdampak pada perilaku setiap masyarakat, dengan sikap yang baik diharapkan akan menimbulkan perilaku yang baik walaupun tidak selalu. Faktor yang mempengaruhi sikap terhadap objek sikap yaitu pengalaman pribadi yang meninggalkan kesan yang kuat dan pengaruh orang lain yang dianggap penting (Sari, 2017; Kurniawan, 2018).

Namun, dalam penelitian ini ditemukan bahwa sikap responden yang positif dalam perilaku pencegahan COVID 19 tidak menjamin perilaku pencegahan covid-19 yang positif. Hal ini dapat disebabkan karena sikap masih berupa respon tertutup, sehingga sikap positif tersebut juga dituangkan dalam bentuk perilaku yang positif. Selain itu diketahui bahwa sikap responden yang negatif juga cenderung menunjukan perilaku pencegahan COVID 19 yang baik. Kemungkinan yang dapat menjelaskan hal ini adalah pengalaman pribadi responden mengenai pencegahan terhadap COVID 19 yang didapat dari media massa maupun pemberitaan dari media komunikasi lainnya. Hal ini dikarenakan banyaknya himbauan mengenai pencegahan COVID 19 pada media massa dan media komunikasi lainnya seperti media sosial. Selain itu menurut Pakpour dan Griffiths (2020) bahwa ketakutan dalam komunikasi kesehatan dapat mengubah sikap dan perilaku seseorang. Mereka mengasumsikan bahwa seorang individu berpartisipasi dalam perilaku kesehatan ketika mereka merasa keparahan dan kerentanan suatu penyakit tinggi. Dalam hal ini kemungkinan media massa maupun media komunikasi lainnya meningkatkan rasa ketakutan terhadap COVID 19 sehingga menimbulkan perilaku pencegahan.

\section{PENUTUP}

Jenis kelamin berhubungan dengan perilaku pencegahan Covid-19. Namun, umur, status pekerjaan, dan sikap tidak berhubungan dengan perilaku pencegahan Covid-19. Oleh karena itu, perlu adanya edukasi lebih lanjut dengan memperhatikan jenis kelamin dan memberikan perlakuan khusus pada kelompok jenis kelamin. Meskipun tidak ada hubungan umur, status pekerjaan dan sikap dengan perilaku pencegahan, kegiatan komunikasi informasi dan edukasi (KIE) tetap memperhatikan aspek tersebut dengan tujuan agar masyarakat yang menjadi sasaran tetap peduli dan sadar akan pentingnya upaya preventif dan promotif yang dilakukan.

\section{DAFTAR PUSTAKA}

Adityo S, dkk. 2020. Coronavirus Disease 2019: Tinjauan Literatur Terkini Coronavirus Disease 2019: Review of Current Literatures. Jurnal Penyakit Dalam Indonesia, 7(1): 45-67.

Adityo S, dkk. 2020. Coronavirus Disease 2019: Tinjauan Literatur Terkini Coronavirus Disease 2019: Review of Current Literatures. Jurnal Penyakit Dalam Indonesia, 7(1): 45-67.

Cai H. 2020. Sex Difference And Smoking Predisposition In Patients With COVID-19. Lancet Respir Med, Published Online March 11. DOI: $10.1016 / \mathrm{S} 2213-2600(20) 30117-\mathrm{X}$ 42.

Direktorat Jenderal Pencegahan dan Pengendalian Penyakit (P2P). 2020. Pedoman Pencegahan dan Pengendalian Coronavirus Disesase (Covid-19). Jakarta: Kementerian Kesehatan RI.

Edision dkk. 2020. Hubungan Peran Petugas dan Sikap dengan Perilaku Masyarakat Dalam 
Pengelolaan Sampah Rumah Tangga. Ensiklopedia of journal, 2(2): 90-95.

Fang L, Karakiulakis G, Roth M. 2020. Are Patients With Hypertension And Diabetes Mellitus At Increased Risk For COVID-19 Infection? Lancet Respir Med, Published Online March 11. DOI: $10.1016 /$ S2213- 2600(20)30116-8

Farihatun A, Zulazmi M. 2016. Faktor-faktor yang Berhubungan dengan Perilaku Pencegahan Penyakit Malaria Pada Masyarakat di Desa Karyamukti Kecamatan Cibalong Kabupaten Garut Provinsi Jawa Barat. Jurnal Kesehatan Bakti Tunas Husada, 15(1): 109-121.

John Hopkins University \& Meidicine Coronavirus Resource Center, Https://Coronavirus.Jhu.Edu/Map.Html , Pada 25 Maret 2020 Pukul 16.39 WIB.

Kurniawan DA, dkk. 2018. Evaluasi Sikap Siswa SMP terhadap IPA di Kabupaten Muaro Jambi. Jurnal ilmiah DIDAKTIKA, 19(1): 124139.

Maulana, H. Promosi Kesehatan. Jakarta: Penerbit Buku Kedokteran EGC. 2007.

Sari N dan Surahma AM. 2017. Pengetahuan, Sikap dan Pendidikan dengan Perilaku Pengelolaan Sampah di Kelurahan Bener Kecamatan
Tegalrejo Yogyakarta. Jurnal medika respati, 12(2): 74-84.

Setiawan AR, Surotul I. 2020. Lembar Kegiatan Siswa untuk Pembelajaran Jarak Jauh Berdasarkan Literasi Saintifik pada Topik Penyakit Coronavirus 2019 (COVID-19).

Susilo A, dkk. Coronavirus disease 2019. 2020. Tinjauan literatur terkini coronavirus disease 2019: review of current literatures. Jurnal Penyakit Dalam Indonesia, 7(1): 45-67.

Telaumbanua D. 2020. Urgensi Pembentukan Aturan Terkait Pencegahan Covid-19 di Indonesia. Jurnal Pendidikan Sosial dan Agama, 12(01): 5970.

World Health Organization. 2020. Novel Coronavirus.

World Health Organization. Coronavirus disease (COVID-19) advice for the public; 2020.

World Health Organization. Coronavirus disease 2019 (COVID-19) Situation Report-70. WHO; 2020.

Wulandari A., dkk. 2020. Hubungan Karakteristik Individu dengan Pengetahuan tentang Pencegahan Coronavirus Disease 2019 pada Masyarakat di Kalimantan Selatan. Jurnal Kesehatan Masyarakat Indonesia, 15(1):42-46. 